\title{
EVALUASI PROGRAM WAJIB BELAJAR 12 TAHUN PEMERINTAH DAERAH KOTA YOGYAKARTA
}

\author{
Yenny Merinatul Hasanah, Cepi Safruddin Abdul Jabar \\ Tanjung Pauh, Kuantan Singingi (RIAU), Universitas Negeri Yogyakarta \\ gadiancak@yahoo.co.id, cepi_safruddin@uny.ac.id
}

\begin{abstract}
Abstrak
Penelitian ini bertujuan mengevaluasi: (1) pelaksanaan program (2) pencapaian tujuan program, dan(3) hambatan-hambatan pelaksanaan program wajibbelajar 12 tahun di Kota Yogyakarta. Penelitian ini merupakan penelitian evaluasi dengan menggunakan pendekatan kualitatif. Model evaluasi yang digunakan adalah discrepancy evaluation program. Hasil penelitian program wajib belajar 12 tahun di Kota Yogyakarta bukan Compulsory Education, tetapi lebih merupakan Basic Education Program (BEP) yang didasari Universal Besic Education (UBE) yang pada hakekatnya berarti penyediaan akses yang sama untuk mengikuti pendidikan dasar terhadap anak. Hasil penelitian menunjukkan bahwa (1) pelaksanaan Program Wajib Belajar 12 Tahun: (a) kecukupan tanaga pendidik belum terpenuhi pada jenjang SD, (b) ketersediaan sarana prasarana belum terpenuhisecara keseluruhan, dan(c) ketersediaan pembiayaan pendidikan sudah terpenuhi. (2) pencapaian tujuan program wajib belajar 12 tahun: (a) meningkatkan Angka Partisipasi Sekolah (APS), (b) mengurangi Angka Putus Sekolah (APS), (c) meningkatkan Angka Melanjutkan (AM), (d) program wajib belajar sudah dapat meningkatkan anak lulus minimal SMA/SMK dan sederajat, dan (e) terwujudnya perluasan akses dan pemerataan pendidikan untuk semua. (3) Hambatan-hambatan Program Wajib Belajar 12 Tahunadalah: (a)rendahnya daya beli/tingkat partisipasi masyarakat terhadap pembiayaan pendidikan, (b) rendahnya minat anak dan kesadaran orang tua kurang terhadap pentingnya pendidikan untuk masa depan, (c) masih adanya anak putus sekolah di Kota Yogyakarta (d) sosialisasi program wajib belajar 12 tahun kurang maksimal, dan (e) tidak tepatnya subsidi (KMS) pemerintah Kota Yogyakarta.
\end{abstract}

Kata kunci: evaluasi, pelaksanaan program,tujuan program, hambatan program

\section{AN EVALUATION OF THE 12 YEAR COMPULSORY EDUCATION PROGRAM OF THE CITY GOVERNMENT OF YOGYAKARTA.}

Yenny Merinatul Hasanah, Cepi Safruddin Abdul Jabar

Tanjung Pauh, Kuantan Singingi (RIAU), Universitas Negeri Yogyakarta

gadiancak@yahoo.co.id, cepi_safruddin@uny.ac.id

\begin{abstract}
This study aims to: (1) evaluate the implementation (2) achievement of the purpose, and (3) obstacles in the implementation of the 12 year compulsory education program in Yogyakartacity.This study is an evaluation using the qualitative approach.Model used in this research is discrepancy evaluation model. The results of this study that the 12-year compulsory education program Yogyakarta instead of Compulsory Education, but rather the Basic Education Program (BEP) which is based on the Universal Besic Education (UBE) which essentially means providing equal access to basic education.(1) Theresults indicate that in the implementation of the 12 year compulsory education program: (a) the adequacyof educators isnot met, (b) the infrastructure is not ready, and (c) the educational funding isready. (2) The purpose the 12 yearcompulsory education program in the city of Yogyakarta is: (a) to improvethe welfare of the community, (b) to relieve the burden of education costs, (c) to make effort for students to pass a minimum of SMA/SMK and equal, (d) to increase enrollment rates, and (e)to expandaccess and equity in education for all. (3) The obstacles in the implementation of the 12 year compulsory education program are: (a) the low purchasing power and public participation in the funding of education, (b) the low interest in children and awareness of parents about the importance of education for the future, (c) theschool drop out of children in the city of Yogyakarta, (d) the minimum socialization of 12 years compulsory education, and (e) the lack of accuracy (KMS) of government subsidies.
\end{abstract}

Keywords: evaluation, program implementation, program objectives, program constraintsv 


\section{Pendahuluan}

Pendidikan merupakan hal paling penting dan investasi masa yang akan datang dalam suatu negara. Pendidikan merupakan upaya sadar dan terencana dalam menyiapkan pembangunan masyarakat Indonesia untuk meningkatkan taraf hidup masyarakat untuk menjadi lebih baik. Pemerintah mengupayakan pembangunan manusia Indonesia melalui program pendidikan yang dapat memberikan akses dan pemerataan perolehan pendidikan bagi masyarakat Indonesia tanpa terkecuali, sehingga anak usia produktif untuk sekolah tidak putus sekolah ataupun tidak sekolah. Langkah pemerintah Indonesia dalam menangani masalah pemerataan pendidikan melalui pencanangan program wajib belajar yaitu 6 tahun melalui Sekolah Dasar (SD) selama 6 tahun, kemudian wajib belajar 9 tahun melalui Sekolah Lanjutan Tingkat Pertama (SLTP) selama 3 tahun, selanjutnya Pemerintah Kota Yogyakarta meningkatkan wajib belajar 12 tahun sesuai dengan PP tentang wajib belajar bahwa pemerintah daerah dapat meningkatkan jengjang pada program wajib belajar.

Pengertian belajar menurut Illeris (2009, p. 88) "learning is, however, not the same as transformation and change of conduct, because learning may result in a better understanding of a phenomenon, which cannot necessarily be observed as changed conduct". Sedangkan menurut Fry, Ketteridge, \& Marshall (2008, p. 8) menambahkan bahwa "learning is not a single thing; it may involve mastering abstract principles, understanding proofs, remembering factual information, acquiring methods, techniques and approaches, recognition, reasoning, debating ideas, or developing behaviour appropriate to specific situations; it is about change." yang berarti bahwa belajar bukan satu hal, namun mungkin melibatkan penguasaan prinsip-prinsip abstrak, memahami bukti, mengingat informasi faktual, memperoleh metode, teknik dan pendekatan, pengakuan, penalaran, berdebat ide, atau mengembangkan perilaku yang sesuai dengan situasi tertentu. Oleh karena itu, belajar adalah tentang perubahan sebelum dan sesudah belajar.
Menurut Burton (Basleman \& Mappa, 2011, p. 7) "Learning is a change in the individual, due to interaction of that individual and his invironment, which fills a need and makes him more capable of dealing adequately with his environment". Belajar adalah suatu perubahan yang terjadi dalam diri individu yang dihasilkan dari interaksi individu dengan lingkungannya untuk dapat memenuhi kebutuhannya dan menjadikannya lebih mampu melestarikan lingkungannya secara memadai.Hal ini memberikan arti bahwa belajar mencakup perubahan tingkah laku yang bersifat permanen sebagai akibat dari interaksi individu dengan kondisi dalam lingkungannya. Sedangkan menurut Sugihartono, Fathiyah, Harahap, Setiawati, \& Nurhayati, (2007, p. 74), "Belajar merupakan suatu proses perubahan tingkah laku sebagai hasil interaksi individu dengan lingkungannya dalam memenuhi kebutuhan hidupnya".

Berdasarkan pengertian belajar di atas dapat disimpulkan bahwa belajar adalah proses atau usaha yang dilakukan setiap individu untuk memperoleh suatu perubahan tingkah laku tertentu baik dalam bentuk pengetahuan, keterampilan maupun sikap dan nilai yang positif sebagai pengalaman untuk mendapatkan sejumlah kesan dari bahan yang telah dipelajari. Kegiatan belajar tersebut ada yang dilakukan di sekolah, di rumah, dan di tempat lain seperti museum, di laboratorium, di hutan dan dimana saja. Belajar merupakan tindakan dan perilaku yang kompleks. Sebagai tindakan maka belajar hanya dialami oleh individu itu sendiri dan akan menjadi penentu terjadinya atau tidak terjadinya proses belajar.

Menurut Bradley, Tomlinson, \& Gureckis (Ross. 2008, p.168) "We live in a world consisting of concrete experiences. Moment to moment, we learn and make decisions based on these experiences. Given this characterization of our environment, it is unclear what would constitute a true abstraction, let alone how we could acquire and retrieve such knowledge based on the sensory cues provided by the environment". Intinya menurut Bradley, Tomlinson, \& Gureckis bahwa 
manusia hidup di dunia yang terdiri dari pengalaman konkrit. Pengalaman konkrit tersebut ada, karena dari waktu ke waktu kita belajar dan mampu membuat keputusan berdasarkan pengalaman-pengalaman tersebut. Hal ini mengingat karakteristik dari lingkungan kita yang akan mendapatkan dan memberikan pengetahuan berdasarkan dari petunjuk sensorik yang diberikan oleh lingkungan kita.

Menurut Ormrod $(2012$, p.1) beberapa alasan seseorang belajar "Human learning takes many forms....And people learn for many reasons. Some learn for the external rewards their achievements bring for example, for good grades, recognition, or money. But others learn for less obvious, more internal reasons-perhaps to gain a sense of accomplishment and satisfaction, or perhaps simply to make life easier". Manusia belajar akan mengambil banyak bentuk, seseorang belajar karena memiliki berbagai alasan-alasan tertentu. Alasan-alasan ketika orang belajar yaitu untuk mendapatkan imbalan secara eksternal artinya bahwa ketika seorang memiliki prestasi setelah akhir proses belajar akan mendapatkan imbalan, misalnya prestasi yang didapatkan dari hasil akhir belajar seperti mendapatkan nilai yang baik, pengakuan dari orang lain, atau hadiah. Tetapi ada alasan lain seseorang belajar yaitu alasan internal individu tersebut, alasan tersebut seperti untuk mendapatkan kepuasan mendapatkan prestasi atau mungkin hanya untuk mendapatkan kemudahan dalam hidup.

Karakteristik belajar menurut Dumont, Istance, \& Benavides (2010, p.18) "Learner-centred: the environment needs to be highly focused on learning as the principlal activity, not as an alternative to the critical role of teachers and learning professionals but dependent on them". Lingkungan sangat berpengaruh pada proses belajar sebagai kegiatan utama, bukan sebagai alternatif peran (tugas) guru dan pengajar profesional. Lebih lanjut lagi "Profoundly personalised: The learning environment is acutely sensitive to individual and group differences in background, prior knowledges, motivation and abilities, and offers tailored and detailed feedback". Lingkungan belajar sangat sensitif terhadap perbedaan individu dan kelompok pada latar belakang individu, pengetahuan individu, motivasi dan kemampuan individu masing-masing. Oleh karena itu, lingkungan belajar harus mendukung berbagai perbedaan yang dimiliki individu atau kelompok baik latar belakang, pengetahuan, motivasi dan kemampuan masing-masing individu supaya dapat memberikan rasa aman dan kenyaman dalam proses belajar dan dapat tercapainya tujuan dari belajar. Berdasarkan pendapat di atas dapat disimpulkan bahwa tujuan belajar adalah sejumlah hasil belajar yang menunjukkan bahwa siswa telah melakukan belajar yang umumnya meliputi pengetahuan, keterampilan dan sikap-sikap baru yang diharapkan dapat tercapai oleh siswa.

Wajib belajar merupakan salah satu dari program pendidikan yang dicanangkan oleh pemerintah tiap masing-masing negara. Wajib belajar di masing-masing negara berbeda-beda sesuai dengan kebijakan pemerintahannya. Berdasarkan Peraturan Pemerintah Republik Indonesia Nomor 47 Tahun 2008 Tentang Wajib Belajar pasal 1 ayat (1) "Wajib belajar adalah program pendidikan minimal yang harus diikuti oleh warga negara Indonesia atas tanggung jawab pemerintah dan pemerintah daerah". Wajib belajar adalah program pendidikan minimal yang harus diikuti oleh warga negara Indonesia atas tanggung jawab pemerintah dan pemerintah daerah. Wajib belajar ini merupakan salah satu program yang gencar digalakkan oleh Departemen Pendidikan Nasional (Depdiknas). Program ini mewajibkan setiap warga Negara Indonesia untuk bersekolah selama 9 tahun pada jenjang pendidikan dasar, yaitu dari tingkat kelas 1 Sekolah Dasar (SD) atau Madrasah Ibtidaiyah (MI) hingga kelas 9 Sekolah Menengah Pertama (SMP) atau Madrasah Tsanawiyah (MTs), atau bentuk lain yang sederajat.

Menurut Sparta (Rothbard, 1999, p. 19) mengatakan "The full logical conclusion of the compulsory system; absolute State control over the "whole child", uniformity and 
education in passive obedience to State orders". Keseluruhan kesimpulan logis dari sistem wajib belajar adalah kendali penuh negara terhadap "seluruh anak", keseragaman dan pendidikan diatur pada perintah negara. Oleh karena itu, keseluruhan dari sistem wajib belajar diatur khusus oleh undangundang setiap negara yang melaksanakan program wajib belajar. Sekolah-sekolah yang melaksanakan program wajib belajar harus memenuhi standar instruksi yang ditetapkan pemerintah dalam pelaksanaan pendidikan.

Menurut Seel (2012, p.697) mengatakan bahwa "compulsory education refers to the most crucial period of formal education required by law of all children between certain ages in a given country". Seel menyatakan bahwa pendidikan wajib merupakan periode paling penting dari pendidikan formal yang diwajibkan oleh hukum dari setiap negara, pendidikan wajib diberikan kepada semua anak usia tertentu berdasarkan undang-undang negara tersebut.

Menurut Jin \& Zhang (2008, p.1008) "compulsory education is the fundamental education for citizens and is the source of state power, which radically determines thought level, political awareness, cultural sense and production ability of the entire nation". Maksudnya bahwa wajib belajar merupakan pendidikan fundamental untuk masyarakat dan merupakan sumber dari kekuatan negara yang secara radikal ditentukan melalui tingkatan kesadaran, politik, budaya dan kemampuan produksi dari seluruh bangsa. Selanjutnya Jin \& Zhang (2008, p. 1009) mengatakan "... compulsory education is the education of the entire human beings and the education of social citizens". Wajib belajar merupakan pendidikan seluruh umat manusia dan merupakan pendidikan masyarakat sosial. Setanggap dengan forum pendidikan dunia dengan program Education for All untuk membela hak atas akses dan pemerataan pendidikan tanpa terkecuali.

Menurut Kim (2000, p.17) "Education for All is a basic human right at the heart of development. It must be a national and international priority, and it requires a strong and sustained political commitment, enhanced financial allocations and the participation of all. EFA partners in the processes of policy design, strategic planning and the implementation of programmes". Pendidikan untuk semua adalah hak asasi manusia dari inti pembangunan. Hal ini harus menjadi prioritas nasional maupun internasional untuk memberikan kesempatan yang sama dalam mendapatkan pendidikan. Membutuhkan komitmen kebijakan yang kuat dan berkelanjutan, alokasi keuangan ditingkatkan dan partisipasi semua mitra EFA dalam proses kebijakan yang akan dilakukan, perencanaan strategis dan pelaksanaan program. Oleh karena itu, untuk mencapaienam gol yang telah dirancang dalam pencapaian EFA memerlukanstrategi yang tepat sehingga tercapainya Pendidikan untuk Semua (PUS).

Menurut Amuda (2011, p.3027) mengatakan bahwa "Section 15 of the Nigerian Child Act 2003 provides that a child has the right to free, compulsory, and universal basic education and the parents should ensure that their children attend primary and junior secondary school as stated in the Act". Pemerintah negara Nigeria memberikan hak hukum pada anak untuk memiliki akses pendidikan. Peraturan tersebut terdapat pada bagian 15 dari undang-undang anak Nigeria tahun 2003 yang menetapkan seorang anak memiliki hak untuk mendapatkan pendidikan dasar universal dan orang tua harus memastikan bahwa anak-anak mereka bersekolah di SD dan SMP sebagaimana yang tercantum dalam undang-undang. Setiap orang tua yang gagal menyekolahkan anak, maka pemerintah memberikan teguran sebanyak dua kali. Teguran yang pertama sebagai peringatan, sedangkan teguran yang kedua orang tua diberi hukuman satu bulan penjara.

Beberapa pelaksanaan wajib belajar menurut Vassiliou (2011, p. 9) "In most countries, the start of compulsory education coincides with the start of primary education. Almost everywhere, children who have reached compulsory school age must be enrolled in an educational institution". Intinya sebagian negara, menetapkan pendidikan wajib dimulai dengan pendidikan dasar. Hampir di se- 
tiap negara, anak-anak yang telah mencapai usia wajib belajar harus terdaftar di institusi pendidikan formal, nonformal atau informal dengan kata lain bagi anak-anak usia wajib belajar harus sudah bersekolah.

Progam pendidikan dasar (Basic Education Program) merupakan konsep yang didasari universal basic education (UBE) yang pada hakekatnya berarti penyediaan akses yang sama untuk mengikuti pendidikan dasar terhadap anak. Pendidikan merupakan hal terpenting dalam mengakhiri kemiskinan dan meningkatkan kemakmuran bersama. Menurut World Bank (2013, p. 1) "Yet 61 million children today are not in school-and there is aboundant evidence that learning outcomes in many developing countries are alarmingly low, especially among disadvantaged population". Terdapat 61 juta anak-anak tidak sekolah diseluruh dunia terutama negara berkembang. Hal ini mengindikasikan bahwa hasil pembelajaran dan pendidikan di berbagai negara berkembang cenderung rendah terutama di kalangan populasi penduduk yang kurang beruntung. Oleh karena itu, dalam strategi pendidikan World Bank 2020 bertujuan untuk menciptakan pendidikan untuk se-mua seperti yang dijelaskan World Bank bahwa "Learning for All means ensuring that all children and youth not just the most privileged or the smartest not only can go to school but can acquire the knowledge and skills they need to lead healthy, productive lives, secure meaningful jobs, and contribute to society".

Berdasarkan hasil penelusuran, belum pernah dilaksanakan penelitian terkait dengan program wajib belajar 12 tahun di Kota Yogyakarta.Oleh sebab itu, penelitian ini mengarah kepada evaluasi program wajib belajar 12 tahun di Kota Yogyakarta. Aspek pelaksanaan program yang meliputi kecukupan pendidik, ketersediaan sarana dan prasarana pendidikan, dan ketersediaan pembiayaan. Aspek kedua yaitu pencapaian tujuan program wajib belajar 12 tahun, dan aspek ketiga yaitu hambatanhambatan program wajib belajar 12 tahun di Kota Yogyakarta.

Evaluasi program wajib belajar 12 tahun di Kota Yogyakarta akan dilaksana- kan di Dinas Pendidikan Kota Yogyakarta. Evaluasi program wajib belajar 12 tahu penting dilakukan untuk mengumpulkan data mengenai kondisi nyata sesuatu hal, sejauh mana, dalam hal apa, dan bagian mana tujuan yang sudah tercapai. Hasil evaluasi akan menemukan kelebihan dan kelemahan program. Kelemahan dan kelebihan program tersebut dianalisis dan dicari solusinya untuk menemukan sebuah rekomendasi bagi pelaksanaan program wajib belajar 12 tahun di Kota Yogyakarta yang efektif.

Worthen \& Sanders (1980, p. 19), memberikan pendapat tentang definisi evaluasi sebagai berikut "Evaluation is the determination of the worth of a thing. It includes information for use in judging the worth of the potential utility of alternative approaches designed to attain specified objectives". Pernyataan tersebut mengimplikasikan adanya standar atau kriteria tertentu yang digunakan untuk menentukan nilai. Kriteria yang digunakan dalam penelitian ini salah satunya berasal dari penelitian-penelitian yang relevan terkait program wajib belajar. Penelitian ini akan menggunakan data kualitatif.

Menurut Patton (2002, p.10) metode kualitatif dalam evaluasi "Qualitative methods are often used in evaluations because they tell the programs story by capturing and communicating the participants stories. Evaluation case studies have all the elements of a good story. Qualitative findings in evaluation illuminate the people behind the numbers and put faces on the statistics, not to make hearts bleed, though that may occur, but to deepen understanding". Menurut Patton metode kualitatif sering digunakan dalam evaluasi karena data kualitatif akan menceritakan program dengan menangkap dan menceritakan orang-orang yang terlibat dalam program. Data kualitatif dalam sebuah evaluasi dapat memberikan kejelasan dan pemahaman yang mendalam terhadap suatu program yang sedang dievaluasi.

\section{Metode}

Jenis penelitian yang digunakan dalam penelitian ini adalah penelitian eva- 
luasi dengan metode kualitatif. Selain sebagai rekomendasi terhadap pengambil keputusan, penelitian ini juga memperkaya pengetahuan tentang standar pelaksanaan program wajib belajar 12 tahun.Model evaluasi yang digunakan dalam penelitian ini adalah discrepancy evaluation model yang dikembangkan oleh Malcolm Provus.

Tempat penelitian ini adalah Dinas Pendidikan Kota Yogyakarta dan lingkungan masyarakat Kota Yogyakarta. Waktu penelitian ini dilakukan selama 4 bulan yaitu bulan Februari-Mei 2015. Subjek penelitian ini adalah kepala bagian pendidikan dasar, kepala bagian pendidikan menengah, subag Analisis Data Pendidikan (ADP), masyarakat kota, anak-anak putus sekolah, anak kota yang sekolah di luar Kota Yogyakarta, dan anak luar Kota Yogyakarta yang sekolah di kota.

Data penelitian ini berupa data kualitatif. Data kualitatif dikumpulkan menggunakan pencermatan dokumen, dan wawancara. Pedoman wawancara ditujukan kepala bagian pendidikan dasar, kepala bagian pendidikan menengah, subag ADP, masyarakat kota, anak-anak putus sekolah, anak kota yang sekolah di luar kota, dan anak luar kota yang sekolah di kota. Pencermatan dokumen dilakukan dengan menganalisis dokumen berdasarkan: (1) profil Dinas Pendidikan Kota Yogyakarta; (2) data Rencana Pembangunan Jangka Menengah Daerah (RPJMD) Kota Yogyakarta; (3) data Rencana Strategis (RENSTRA) Dinas Pendidikan Kota Yogyakarta; (4) Data Rencana Kerja (RENJA) Dinas Pendididkan Kota Yogyakarta; dan (5) data Laporan Akuntabilitas Kinerja Instansi Pemerintah (LAKIP).

\section{Hasil Penelitian dan Pembahasan}

Hasil penelitian program wajib belajar 12 tahun Kota Yogyakarta yang mencakup dengan pelaksanaan program wajib belajar 12 tahun meliputi kecukupan pendidik, ketersediaan sarana dan prasarana pendidikan, ketersediaan pembiayaa. Serta pencapaian tujuan program, dan hambatan-hambatan dalam pelaksanaan program wajib belajar 12 tahun di Kota Yogyakarta.
Data hasil penelitian menunjukan bahwa program wajib belajar 12 tahun Kota Yogyakarta belum memiliki payung hukum, tidak adanya sanksi bagi yang melanggarnya, pengaturan program dilakukan oleh pemerintah daerah.Data hasil penelitian pada pelaksanaan program wajib belajar 12 tahun yang meliputi: Perkembangan jumlah pendidik di Kota Yogyakarta berdasarkan data mengalami penurunan jumlah pendidik disemua jenjang pendidikan SD+MI, SMP+MTs, dan SMA+ MA+SMK, hal tersebut dikarenakan oleh purna tugas, pendidik sudah lanjut usia serta mendekati masa pensiun. Kecukupan jumlah pendidik kelas pada jenjang pendidikan SD+MI masih kurang 52 orang sampai dengan tahun 2015, sedangkan pada jenjang pendidikan, SMP+MTs dan SMA+ MA+SMK sudah terpenuhi. Permasalahan lain yang ada pada pendidik di Kota Yogyakarta adalah jumlah pendidik yang menurun setiap tahunnya pada jenjang pendidikan SD+MI, SMP+MTs, dan SMA+MA $+\mathrm{SMK}$, beberapa alasan menurunnya jumlah pendidik yaitu purna tugas dan pensiun. Permasalahan selanjutnya yang dihadapi Dinas Pendidikan Kota Yogyakarta adalah masih banyak guru yang tidak layak untuk mengajar yang dibuktikan dengan dokumen terkait kondisi pendidik di Kota Yogyakarta sampai pada tahun 2013/ 2014 guru yang tidak layak mengajar pada jenjang SD+MI sebanyak 218, pada jenjang $\mathrm{SMP}+\mathrm{MT}$ guru yang tidak layak mengajar berjumlah 71, sedangkan pada jenjang SMA+MA+SMK guru yang tidak layak mengajar berjumlah 265 .

Ketersediaan Sarana dan prasarana dalam pelaksanaan program wajib belajar 12 tahun di Kota Yogyakarta pada jenjang SD+MI pendidikan SD+MI terdapat dua indikator mutu yang pertama kondisi ruang kelas dalam kondisi baik meningkat, pada tahun $2008 / 2009$ sebesar $86 \%$ pada tahun 2013/2014 meningkat menjadi 94\%, ruang kelas kondisi rusak ringan mengalami penurunan setiap tahunnya pada tahun $2008 / 2009$ sebesar $8,04 \%$ pada tahun 2013/2014 menjadi 4,72\%, sedangkan pada ruang kelas kondisi rusak berat mengalami 
penurunan dimulai pada tahun 2008/2009 sebesar $5,44 \%$ pada tahun $2013 / 2014$ menjadi $0,58 \%$. Indikator mutu kedua yaitu fasilitas sekolah seperti perpustakaan meningkat diawali pada tahun 2008/2009 sebesar $60,16 \%$ pada tahun $2013 / 2014$ sebesar $102,83 \%$, dan fasilitas sekolah Unit Kesehatan Sekolah (UKS) mengalami kenaikan dimulai pada tahun 2009/2010 sebesar $4,75 \%$ pada tahun 2013/2014 menjadi $108,06 \%$

Sarana dan prasarana SMP+MTs terdapat dua indikator mutu yang pertama kondisi ruang kelas dalam kondisi baik menurun dua tahun terakhir, pada tahun $2008 / 2009$ sebesar $96,83 \%$ pada tahun 2013/2014 menurun menjadi 95,86\%, ruang kelas kondisi rusak ringan mengalami kenaikan setiap tahunnya pada tahun 2008/ 2009 sebesar 2,39\% pada tahun 2013/2014 menjadi 3,89\%, sedangkan pada ruang kelas kondisi rusak berat mengalami penurunan dimulai pada tahun 2008/2009 sebesar $0,77 \%$ pada tahun 2013/2014 menjadi $0 \%$. Indikator mutu kedua yaitu fasilitas sekolah seperti perpustakaan menurunt diawali pada tahun 2008/2009 sebesar $101,14 \%$ pada tahun 2013/2014 sebesar 91,40\%, dan fasilitas sekolah Unit Kesehatan Sekolah (UKS) mengalami kenaikan dimulai pada tahun 2008/2009 sebesar $78,80 \%$ pada tahun 2013/2014 menjadi $485,71 \%$, dan fasilitas sekolah laboratorium mengalami kenaikan dimulai pada tahun $2008 / 2009$ sebesar $273,31 \%$ pada tahun 2013/2014 menjadi 293,14\%.

Berdasarkan SNP pada pasal 42 ayat (1) yang harus dipenuhi standar sarana dan prasarana pendidikan adalah "Setiap satuan pendidikan wajib memiliki sarana yang meliputi perabot, peralatan pendidikan, media pendidikan, buku dan sumber belajar lainnya, bahan habis pakai, serta perlengkapan lain yang diperlukan untuk menunjang proses pembelajaran yang teratur dan berkelanjutan". Pada ayat (2) "Setiap satuan pendidikan wajib memiliki prasarana yang meliputi lahan, ruang kelas, ruang pimpinan satuan pendidikan, ruang pendidik, ruang tata usaha, ruang perpustakaan, ruang laboratorium, ruang bengkel kerja, ruang unit produksi, ruang kantin, instalasi daya dan jasa, tempat berolahraga, tempat beribadah, tempat bermain, tempat berkreasi, dan ruang/tempat lainyang diperlukan untuk menunjang proses pembelajaran yang teratur dan berkelanjutan".

Ketersediaan sarana dan prasarana pendidikan SD+MI dan SMP+MTs dalam program wajib belajar 12 tahun ditemukan kensenjangan-kesenjangan yang mengacu pada pemenuhan SNP pada standar sarana dan prasarana pendidikan. Sarana dan prasarana pada jenjang SMP+MTs yang belum terpenuhi adalah fasilitas sekolah seperti lapangan olahraga, ruang keterampilan, bimbingan penyuluhan, dan ruang serba guna. Pemenuhan standar sarana dan prasarana berdasarkan SNP yang sulit untuk terpenuhi dengan alasan ketersediaan lahan sekolah, pembiayaan sarana dan prasaran pendidikan.

Sedangkan sarana dan prasarana $\mathrm{SMA}+\mathrm{MA}+\mathrm{SMK}$ terdapat dua indikator mutu yang pertama kondisi ruang kelas dalam kondisi baik menurun, pada tahun 2008/2009 sebesar $99,46 \%$ pada tahun 2013/2014 menurun menjadi 99,06\%, ruang kelas kondisi rusak ringan mengalami kenaikan setiap tahunnya pada tahun 2008/ 2009 sebesar 0,29\% pada tahun 2013/2014 menjadi $0,94 \%$, sedangkan pada ruang kelas kondisi rusak berat mengalami penurunan dimulai pada tahun 2008/2009 sebesar $0,26 \%$ pada tahun 2013/2014 menjadi $0 \%$. Indikator mutu kedua yaitu fasilitas sekolah seperti perpustakaan menurun diawali pada tahun 2008/2009 sebesar $108,66 \%$ pada tahun 2013/2014 sebesar 90,36\%, fasilitas sekolah Unit Kesehatan Sekolah (UKS) mengalami penurunan dimulai pada tahun 2008/2009 sebesar 95,67\% pada tahun 2013/2014 menjadi $87,95 \%$, laboratorium mengalami penurunan diawali pada tahun 2008/2009 sebesar $402,79 \%$ pada tahun $2013 / 2014$ menjadi $396,39 \%$, ruang keterampilan menurun diawali pada tahun 2008/2009 sebesar $47,02 \%$ pada tahun 2013/2014 sebesar $31,33 \%$, ruang bimbingan penyuluhan mengalami penurunan dimulai pada tahun 
$2008 / 2009$ sebesar $103,87 \%$ pada tahun $2013 / 2014$ menjadi $81.93 \%$, ruang serba guna mengalami penurunan diawali pada tahun $2008 / 2009$ sebesar $85,99 \%$ pada tahun 2013/2014 menjadi 62,71\%, ruang bengkel mengalami peningkatan dimulai pada tahun $2008 / 2009$ sebesar $27,59 \%$ pada tahun 2013/2014 menjadi 71,88\%, ruang praktek mengalami kenaikan diawali pada tahun 2008/2009 sebesar $104,60 \%$ pada tahun 2013/2014 menjadi 412,50\%,

Berdasarkan SNP pada pasal 42 ayat (1) yang harus dipenuhi standar sarana dan prasarana pendidikan adalah "Setiap satuan pendidikan wajib memiliki sarana yang meliputi perabot, peralatan pendidikan, media pendidikan, buku dan sumber belajar lainnya, bahan habis pakai, serta perlengkapan lain yang diperlukan untuk menunjang proses pembelajaran yang teratur dan berkelanjutan". Pada ayat (2) "Setiap satuan pendidikan wajib memiliki prasarana yang meliputi lahan, ruang kelas, ruang pimpinan satuan pendidikan, ruang pendidik, ruang tata usaha, ruang perpustakaan, ruang laboratorium, ruang bengkel kerja, ruang unit produksi, ruang kantin, instalasi daya dan jasa, tempat berolahraga, tempat beribadah, tempat bermain, tempat berkreasi, dan ruang/ tempat lainyang diperlukan untuk menunjang proses pembelajaran yang teratur dan berkelanjutan".

Ketersediaan sarana dan prasarana pendidikan dalam program wajib belajar 12 tahun ditemukan kensenjangan-kesenjangan yang mengacu pada pemenuhan SNP pada standar sarana dan prasarana pendidikan. Sarana dan prasarana pada jenjang SMA+MA+SMK yang belum terpenuhi adalah fasilitas sekolah seperti lapangan olahraga, pemenuhan standar sarana dan prasarana berdasarkan SNP yang sulit untuk terpenuhi dengan alasan ketersediaan lahan sekolah, pembiayaan sarana dan prasaran pendidikan.

Ketersediaan pembiayaan pendidikan dalam program wajib belajar 12 tahun di Kota Yogyakarta melalui BOS pusat, BOSDA Provinsi, JPD, dan BOSDA/BOP Kota Yogyakarta. Pemerintah Kota Yogya- karta dalam menganggarkan biaya untuk program wajib belajar 12 tahun dengan jumlah Rp101.282.890.200 terbagi menjadi dua kegiatan yaitu pengelolaan JPD dan pengelolaan BOS dan BOSDA.Besaran dana BOSDA DIKDAS sama antara SD Negeri/Swasta dan MI Swasta yaitu sebesar Rp110.000/siswa dalam setahun, sedangkan besaran dana BOSDA untuk jenjang pendidikan SMP Negeri/Swasta dan MTs Swasta sebesar Rp190.000/siswa dalam setiap tahunnya. Sedangkan Nilai bantuan BOSDA Pendidikan Menengah diberikan pertahun pada siswa SMA/SMK/MA. Setiap anak SMA negeri/swasta mendapatkan dana BOSDA sebesar Rp250.000/tahun, siswa SMK negeri/swasta mendapatkan dana BOSDA sebesar Rp600.000/tahun, sedangkan MA swasta mendapatkan dana BOSDA sebesar Rp250.000/tahun. Nilai dana BOSDA berbeda antara siswa sekolah di SMA, SMK, atau MA.

Besaran JPD yang diterima dalam satu tahun pelajaran bagi anak pemegang KMS baik yang sekolah di kota maupun anak yang bersekolah di luar kota dalam wilayah DIY memiliki jumlah yang berbeda antara siswa sekolah negeri dan sekolah swasta di semua jenjang pendidikan, baik SD/MI, SMP/MTs ataupun SMA/MA/ SMK. Jumlah yang diterima sekolah negeri SD/MI sebesar Rp700.000, SMP/MTs Rp800.000, dan SMA/MA/SMK Rp3.000.0000 sedangkan sekolah swasta SD/MI Rp1.700.000, SMP/MTs Rp2.500.000, SMA/MA Rp3.500.000, dan SMK Rp4.500.000.

Tujuan program wajib belajar 12 tahun di Kota Yogyakarta yang harus dicapai adalah meningkatkan Angka Partisipasi Sekolah (APS) 97\%, mengurangi Angka Putus Sekolah (APS) menjadi 0,02\%, meningkatkan Angka Melanjutkan (AM) $120 \%$, meningkatkan angka anak lulusan SMA/MA/SMK dan sederajat, dan terwujudnya perluasan akses dan pemerataan pendidikan.

Pencapaian tujuan dalam program wajib belajar 12 tahun di Kota Yogyakarta yang pertama meningkatkan APS di Kota Yogyakarta untuk keseluruhan anak usia 
TK, SD, SMP, dan SMA/SMK. APS Kota Yogyakarta tahun 2014 pada kategori usia anak 7-12 tahun mencapai 98\%, kategori usia anak 13-15 tahun mencapai 97\%, sedangkan pada kategori usia anak 16-18 tahun mencapai $82 \%$. APS pada jenjang SD+MI, SMP+MTs sudah mencapai target tujuan, sedangkan pada jenjang SMA+MA +SMK belum mencapai target tujuan program wajib belajar 12 tahun.

Capaian tujuan yang kedua untuk mengurangi Angka Putus Sekolah. Perkembangan Angka Putus Sekolah Kota Yogyakarta enam tahun terakhir adalah pada jenjang pendidikan SD+MI pada tahun 2007 sebesar 0,05\%, 2008 sebesar 0,07\%, 2009 sebesar $0,02 \%$, 2010 sebesar $0,02 \%$, 2011 sebesar 0,019\%, 2012 sebesar 0,01\%. Pendidikan SMP+MTs pada tahun 2007 sebesar 0,18\%, 2008 sebesar 0,33\%, 2009 sebesar 0,01\%, 2010 sebesar 0,05\%, 2011 sebesar 0,03\%, 2012 sebesar 0,03\%. Pendidikan SMA+MA+SMK pada tahun 2007 sebesar 0,92\%, 2008 sebesar 0,45\%, 2009 sebesar 0,09\%, 2010 sebesar 0,07\%, 2011 sebesar $0.04 \%, 2012$ sebesar 0,05\%. Kota Yogyakarta pada jenjang pendidikan SD+ MI sudah mencapai target pencapaian program wajib belajar 12 tahun sebesar 0,01\% sampai tahun 2012, pada jenjang pendidikan SMP+MTs capaian sebesar 0,03\% sampai tahun 2012 belum mencapai target tujuan program wajib belajar 12 tahun $0,02 \%$, sedangkan pada pendidikan SMA+MA+SMK capaian APS sampai tahun 2012 sebesar 0,05\% artinya belum mencapai tujuan program wajib belajar 12 tahun. Penyebab anak mengalami putus sekolah diantaranya ekonomi keluarga, minat anak yang kurang untuk belajar, kemampuan anak dalam belajar, motivasi orang tua untuk menyekolahkan anak kurang, geografis sekolah maupun rumah, penduduk anak usia sekolah yang berada di luar DIY yang tidak bersekolah, karena pemerintah daerah hanya menjangkau anak-anak usia sekolah yang berada di wilayah DIY dan bersekolah di wilayah DIY.

Tujuan ketiga meningkatkan AM. Perkembangan AM dari jenjang pendidikan SD/MI ke jenjang pendidikan SMP/
MTs pada tahun 2008/2009 sebesar $111,60 \%$, 2009/ 2010 sebesar 120,43\%, 2010/ 2011 sebesar 110,91\%, 2011/2012 sebesar 110,54\%, 2012/2013 sebesar 110,51\%, dan 2013/2014 sebesar 109,49\%. Angka melanjutkan dari jenjang pendidikan SMP/MTs ke jenjang pendidikan SMA/MA/SMK dari tahun 2008/2009 sebesar 165,57\%, 2009/ 2010 sebesar 145,69\%, 2010/2011 sebesar 158,21\%, 2011/2012 sebesar 158,98\%, 2012/ 2013 sebesar 169,98\%, dan 2013/2014 sebesar 160,59\%. Capaian AM Kota Yogyakarta dalam program wajib belajar 12 tahun berdasarkan standar yang telah ditentukan berdasarkan RENJA Pemerintah Kota Yogyakarta sebesar $120 \%$, pada jenjang pendidikan SD+MI melanjutkan pada jenjang SMP+MTs belum mencapai target capaian sampai tahun 2013/2014 mencapai $109,49 \%$, sedangkan pada jenjang SMP+ MTs melanjutkan pada jenjang SMA+MA+ SMK sudah mencapai target capaian melebihi angka $120 \%$ yaitu sebesar $160,59 \%$ pada tahun 2013/2014.

Tujuan keempat yang harus dicapai adalah meningkatkan angka kelulusan anak. Perkembangan angka kelulusan Kota Yogyakarta enam tahun terakhir pada jenjang SD+MI pada tahun 2007 sebesar 94,30\%, dan pada tahun 2008-2012 mencapai angka $100 \%$ kelulusan, pada jenjang SM+MTs tahun 2007 sebesar $88,15 \%$, pada 2008 menjadi $92,80 \%$, pada 2009 menjadi $94,55 \%$, pada 2010 menjadi $91.13 \%$, pada 2011 menjadi 99,83\%, dan pada tahun 2012 mencapai $98,83 \%$, sedangka pada jenjang SMA+MA pada tahun 2007 sebesar 94,68\%, pada 2008 menjadi 93,63\%, pada 2009 menjadi $93.74 \%$, pada 2010 menjadi 94,51\%, pada 2011 menjadi 99,35\%, dan pada tahun 2012 mencapai 99.52\%, dan pada jenjang SMK pada tahun 2007 sebesar $86,69 \%$, pada 2008 menjadi $82,52 \%$, pada 2009 menjadi $97,32 \%$, pada 2010 menjadi $96,81 \%$, pada 2011 menjadi 99,18\%, dan pada tahun 2012 mencapai 99,23\%. Hasil kelulusan pada semua jenjang pendidika SD+MI, SMP+ MTs, dan SMA+MA+SMK dalam program wajib belajar 12 tahun Kota Yogyakarta memiliki tren yang positif mengalami kenaikan dari tahun 2007 sampai dengan 
tahun 2012. Tujuan program tersebut tentu untuk dapat meluluskan warganya minimal pendidikan SMA/MA/SMK dan sederajat, sedangkan pemerintah memiliki istilah yang sama yaitu Pendidikan Menengah Universal (PMU).

Tujuan kelima yang harus dicapai dalam program wajib belajar 12 tahun adalah terwujudnya perluasan akses pendidikan dan pemerataan pendidikan seluasluasnya untuk semua di Kota Yogyakarta. Melalui program wajib belajar 12 tahun Pemerintah Kota Yogyakarta memberikan kesempatan perolehan pendidikan bagi masyarakat Kota Yogyakarta secara keseluruhan tanpa terkecuali.

Hambatan-hambatan yang terjadi dalam pelaksanaan program wajib belajar 12 tahun di Kota Yogyakarta. Hambatan pertama daya beli/tingkat partisipasi masyarakat terhadap pembiayaan pendidikan masih kurang. Alasan lain yang menjadi kurangnya partisipasi masyarakat dalam mendukung program wajib belajar 12 tahun adalah minimnya informasi terkait program-program tersebut sehingga orang tua atau anak tidak mengetahui adanya program tersebut seperti program JPD untuk mendapatkannya harus memiliki KMS, dan BOSDA, sekolah swasta memungut biaya operasional sekolah.

Hambatan kedua minat anak dan kesadaran orang tua kurang terhadap pentingnya pendidikan untuk masa depan. Dinas Pendidikan Kota Yogyakarta selain mengarahkan untuk anak melanjutkan sekolah sampai 12 tahun melalui sekolah formal, Dinas Pendidikan Kota Yogyakarta juga mengarahkan ke sekolah non formal, sekolah informal atau kesetaraan (paket C),

Hambatan ketiga masih adanya anak putus sekolah di Kota Yogyakarta. Beberapa kasus anak yang putus sekolah sebagian besar tidak memiliki motivasi diri untuk tetap sekolah, tetapi beberapa anak mengatakan bahwa orang tua tidak mendukung terkait biaya pendidikan walaupun pendidikan gratis akan tetapi kebutuhan yang lain masih banyak yang harus dipenuhi seperti seragam sekolah, iuraniuran sekolah yang masih ada, atau tam- bahan referensi buku sehingga memberatkan orang tua. Orang tua lebih senang anak bekerja untuk membantu perekonomian keluarga. Alasan lain mereka tidak sekolah adalah karena mereka harus menikah disaat mereka masih sekolah.

Hambatan kelima sosialisasi program wajib belajar 12 tahun yang belum maksimal. Informasi yang diperoleh masyarakat masih kurang merata, kasus dilapangan atau di masyarakat sering terjadi ketidak sesuaian informasi yang diperoleh masyarakat dari perangkat atau pejabat yang berwenang. Jika mereka sibuk dengan bekerja mereka tidak akan mengikuti kumpulan RT/RW yang sedang mensosialisasikan tertakait program wajib belajar 12 tahun, yang lebih menjadi ironis lagi pejabat pemerintahan setempat kelurahan dan jajarannya menganggap bahwa seluruh warganya sudah mengetahui informasi wajib belajar 12 tahun.

Hambatan keenam ketidak tepatan subsidi pemerintah terkait KMS.KMS merupakan hasil kebijakan pemerintah daerah Kota Yogyakarta. Masyarakat Kota Yogyakarta yang merupakan keluarga pemegang KMS mendapatkan JPD. Program JPD merupakan wujud dari pendidikan gratis di Kota Yogyakarta, karena JPD merupakan bentuk komitmen Pemerintah Daerah Kota Yogyakarta dalam memberikan jaminan pendidikan, bukan hanya wajib belajar 9 tahun, namun wajib belajar 12 tahun, serta memberikan kesempatan yang luas bagi masyarakat Kota Yogyakarta untuk mendapatkan pendidikan yang berkualitas.

Penerima JPD akan mendapatkan jaminan berupa biaya pendidikan, penerima JPD juga mendapatkan beberapa keuntungan. Pertama, penerima JPD KMS mendapatkan kuota KMS dalam penerimaan peserta didik baru (PPDB), yaitu dengan memberikan kuota tertentu bagi peserta didik pemegang KMS dalam PPBD supaya dapat mengakses sekolah favorit. Kedua, penerima JPD KMS diberikan kepada peserta didik setiap jenjang pendidikan dari TK sampai SMA baik sekolah negeri maupun swasta, serta sekolah luar biasa. Ketiga, penerima JPD KMS tetap akan di- 
berikan bagi peserta didik pemegang KMS baik yang sekolah di Kota Yogyakarta maupun luar Kota Yogyakarta.

Jumlah anak pemegang KMS dari jenjang pendidikan TK sampai dengan jenjang pendidikan SMA di Kota Yogyakarta pada tahun 2011 sebanyak 14. 175 anak, tahun 2012 sebanyak 13.012 anak, tahun 2013 sebanyak 15.046 anak, dan pada tahun 2014 sebanyak 14.923 anak. KMS diberikan kepada anak yang sekolah dalam Kota Yogyakarta maupun sekolah luar Kota Yogyakarta, baik sekolah negeri maupun sekolah swasta.

\section{Simpulan dan Saran}

Berdasarkan hasil penelitian yang telah dilaksanakan bahwa program wajib belajar 12 tahun di Kota Yogyakarta bukan Compulsory Education, tetapi lebih merupakan Basic Education Program(BEP) yang didasari Universal Besic Education (UBE) yang pada hakekatnya berarti penyediaan akses yang sama untuk mengikuti pendidikan dasar terhadap anak.

Pelaksanaan program wajib belajar 12 tahunyaitu kecukupan pendidik dalam program wajib belajar 12 tahun di Kota Yogyakarta belum terpenuhi diantaranya adalah jumlah guru kelas pada Sekolah Dasar (SD) kurang terpenuhi sampai tahun 2015 kekurangan jumlah guru tersebut mencapai jumlah 52 orang, jumlah guru menurun setiap tanunnya disebabkan oleh sudah berusia lanjut dan mendekati purna tugas. Ketersediaan sarana prasarana sekolah di Kota Yogyakarta belum terpenuhi secara keseluruhan.Ketersediaan pembiayaan pendidikan di Kota Yogyakarta sudah tersedia yang bersumber dari Pemerintah, Pemerintah Daerah Istimewa Yogyakarta, dan Pemerintah Daerah Kota Yogyakarta.

Pencapaian tujuan program wajib belajar 12 tahun berdasarkan hasil penelitian yang telah dilaksanakan di Dinas Pendidikan Kota Yogyakarta adalah: Meningkatkan Angka Partisipasi Sekolah (APS) sudah mencapai tujuan melebihi $97 \%$ yaitu jenjang SD+MI mencapai 97\%, jenjang $\mathrm{SMP}+\mathrm{MT}$ mencapai $82 \%$, seangkan pada jenjang SMA+MA+SMK mencapai $82 \%$ belum mencapai target tujuan program wajib belajar 12 tahun, mengurangi Angka Putus Sekolah (APS) pada jenjang SD+MI, jenjang SMP+MTs, dan jenjang SMA+MA+ SMK belum memenuhi 0,02\%, meningkatkan Angka Melanjutkan (AM) pada jenjang SD+MI melanjutkan pada jenjang SMP+ MTs sampai tahun 2013/2014 sebesar $109,49 \%$ artinya belum mencapai $120 \%$, dan pada jenjang SMP+MTs melanjutkan jenjang SMA+MA+SMK sudah mencapai target pada tahun 2013/2015 sebesar $160,59 \%$ melebihi target capaian program wajib belajar 12 tahun sebesar $120 \%$, program wajib belajar sudah dapat meningkatkan anak lulus minimal SMA/SMK dan sederajat, dan terwujudnya perluasan akses dan pemerataan pendidikan untuk semua.

Hambatan-hambatan Pelaksanaan Program Wajib Belajar 12 Tahun: Daya beli/tingkat partisipasi masyarakat terhadap pembiayaan pendidikan, minat anak dan kesadaran orang tua kurang terhadap pentingnya pendidikan untuk masa depan, masih adanya anak putus sekolah di Kota Yogyakarta, sosialisasi program wajib belajar 12 tahun kurang maksimal, dan ketidaktepatan subsidi pemerintah terkait pendataan masyarakat miskin sehingga berpengaruh pada pembagian kartu dan kurangnya cross check ke lapangan terkait data masyarakat Kota Yogyakarta yang kurang mampu.

Melhat kondisi yang ada dilapangan dapat dirumuskan beberapa saran sebagi berikut: Melihat jumlah masyarakat Kota Yogyakarta masih ada yang belum mendapatkan KMS, maka pemerintah Kota Yogyakarta perlu melakukan pengecekan secara langsung data penerima KMS yang telah ada di dinas kependudukan/dinas sosial supaya tepat sasaran bagi pengguna KMS, informasi program wajib belajar 12 tahun harus jelas dan tersebar secara luas kepada masyarakat. Dinas harus memastikan secara teliti bahwa informasi program wajib belajar 12 tahun sampai kepada masyarakat, supaya masyarakat tidak bias akan informasi, negara bertanggung jawab atas anak-anak yang kurang mampu untuk 
mendapatkan pendidikan gratis dan tidak adanaya alasan bagi peserta didik yang tidak mampu tidak mendapatkan pendidikan yang layak.

\section{Daftar Pustaka}

Amuda, Y. J. (2011). Child education in nigeria: Hindrances and legal solutions. Procedia Social and Behavioral Sciences, 15, 3027-3031.

Basleman, A., \& Mappa, S. (2011). Teoribelajar orang dewasa. Bandung: Remaja Rosdakarya.

Dumont, H., Istance, D., \& Benavides, F. (2010). The natural of lerning: Using research to inspire practice. Paris: OECD.

Fry, H.,Keteridge, S.,\& Marshall, S. (2009). A hanbook for teaching and learning in higher education enhancing academic practice( $3^{\text {thed.). }}$.New York: Roudledge.

Illeris, K. (2009). Contemporary theories of learning: Learning theorist in their own word. New York: Routledge.

Jin, Y., \& Zhang, H. (2008). Research on the costs of running compulsory education standards: Comparison of compulsory education internationally. Internasional Education Studies, 1, 108-111
Kim. J.Y. (2000). The dakarframe work for action. Paris: UNESCO.

Ormrod, J.E. (2012). Human learning (6 $6^{\text {thed.). }}$. New York: Pearson Education, Inc.

Patton, M.Q. (2002). Qualitative research $\mathcal{E}$ evaluation methods (3thed.). Thousand Oaks: Sage Publications, Inc.

Ross, B.H. (2008). The psychology of learning and motivation: Advences in reasearch and theory. Urbana. Elsevier Inc.

Rothbard, M. A. N. (1999). Education free and compulsory.Auburn: Ludwig von Mises Institute.

Seel, N.M. (2012). Encyclopedia of the sciences of learning. New York: Springer.

Sugihartono, Fathiyah, K. N., Harahap, F., Setiawati, F. A., \& Nurhayati, S. R. (2007). Psikologi pendidikan. Yogyakarta: UNY Press.

Vassiliou. A. (2011).Grade retention during compulsory education in europe: Regulation and statistics. Brussels: EACEA P9 Eurydice.

Worthen, B.R. \& Sanders, J.R. (1981). Educational evaluation: Theory $\mathcal{E}$ Practise. Belmont California: Wordsworth Publishing Company Inc. 